\section{Hvem er «verdig trengende» i 2016?}

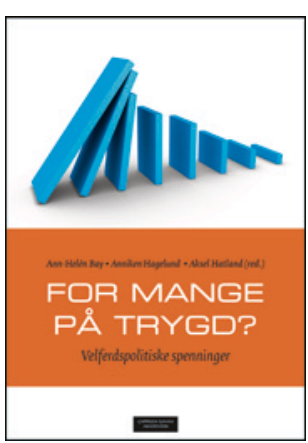

Ann-Helén Bay, Anniken Hagelund,

Aksel Hatland, red.

For mange på trygd?

Velferdspolitiske spenninger. $214 \mathrm{~s}$, tab, ill. Oslo: Cappelen Damm Akademisk, 2015.

Pris NOK 349

ISBN 978-82-02-49470-4

I denne boken settes et akademisk spørsmålstegn ved påstanden om at for mange av oss i Norge er trygdede. Redaktørene drar veksler på et trygdeforskningsprosjekt i perioden $2010-15$ for å belyse det de kaller spenningene i velferdspolitikken der ulike interesser står mot hverandre. I seks kapitler, ett for hvert tema, ser forskere som deltok i prosjektet på noen av dilemmaene. De skriver om bruk av arbeidsplikt for stønadsmottakere og bruk av trygd til atferdsstyring, beskriver omfanget og effekten av arbeidsgivernes (selvrapporterte) inkluderingsinnsats og besøker grasrota for å se på trygdefunksjonærens rolle etter Nav-reformen. Trygdepolitikk og sysselsetting over landegrensene sammenlignes, og mulige konsekvenser av større arbeidsinnvandring til Norge drøftes.

I 1990-årene ble sosialpolitikken lagt om i Norge, siden politikerne mente at for mange var på trygd. Arbeidslinjen ble lansert for at vi skulle «velge arbeid fremfor trygd», som det het. Det nye Nav skulle sørge for at det ble «færre på trygd, flere i arbeid eller aktivitet». Glemt var gamle Rikstrygdeverkets formål om «rett ytelse» til alle. Nye Nav snakker mye om «misbrukerne» som făr for mye, sjelden om dem som ikke får det de skal ha.

Velferdsstaten er ikke for dyr for alle. Redaktørene viser at det ikke finnes noen enkel «kunnskapsbasert» sosialpolitikk hevet over kampen mellom ulike interesser. Språket forteller likevel iblant om en ureflektert aksept av oppdragsgivernes syn på trygd som en uønsket utgift. Nesten alle kaller for eksempel norske trygder for «sjenerøse». Sjenerøs betyr ifølge Bokmålsordboka «høysinnet; edelmodig; gavmild». Det er lettere å forsvare kutt $\mathrm{i}$ «sjenerøse» ordninger enn i forsvarlige, rettferdige, riktige eller nødvendige ordninger, som de er blitt kalt i andre perioder. Den normative bruken av begrepet «arbeidstilbud» er et annet eksempel. Folketrygdens formål er å gi hjelp til selvhjelp slik at «den enkelte skal kunne forsørge seg selv og klare seg selv best mulig». Høyt arbeids(kraft)tilbud gleder investorene, men det er ingen garanti for god hjelp til selvforsørging. Det kan like gjerne bety flere desperate jobbsøkere og mer sosial dumping til mindre attraktive jobber.

Enkelte tabeller og figurer er unødvendig tungleste, men ellers er dette en god samling momenter til diskusjon - et korrektiv til offentlige trygdepolitiske begrunnelser som, for å låne et dristig ordspill fra boken, ofte minner mer om bedrag enn begrunnelser.

\section{Ebba Wergeland}

Overlege, Arbeidstilsynet

\section{Et teknokratisk blikk på velferden}

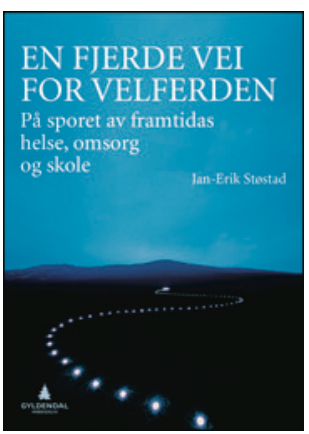

Jan-Erik Støstad

En fjerde vei for velferden

På sporet av framtidas helse, omsorg og skole. 200 s, ill. Oslo: Gyldendal Arbeidsliv, 2015. Pris NOK 298

ISBN 978-82-05-47979-1

Vi strever med å forstå oss på velferdsstaten her oppe i Norden. På den ene siden har vi skapt en samfunnsmodell som blir sett på med tiltagende respekt og beundring i store deler av verden. På den annen side er vi ikke riktig sikre på hva slags skapning denne velferdsstaten er og hva som skal til for å videreutvikle den. Eller, som enkelte med et visst mismot skriver, at vi med ulike slags markedsbaserte reformer er i ferd med å demontere den.

Derfor leser jeg denne boken i største spenning. Dels fordi forfatter og samfunnsøkonom Jan-Erik Støstad, med sin bakgrunn i LO og Arbeiderpartiet, har vært - og er - en av de mest sentrale aktørene i formingen av fremtidens velferdsvisjoner, dels fordi han griper til en så utfordrende tittel som «en fjerde vei for velferden». Selv om han ikke skriver det, må tittelen ses i lys av det som i 1990årene fikk merkelappen «den tredje vei» for velferden, meislet ut av den britiske sosiologen Anthony Giddens i The third way: The renewal of social democracy fra 1998. Med markedets dynamikk som ideal og målstyring som virkemiddel ble sosialdemokratiske regimer over store deler av Europa inspirert til å innføre markedsmodeller i offentlig sektor. Det gikk ikke bare bra, verken for New Public Management eller for sosialdemokratiene, som har høstet mye kritikk for de telle- og måleregimene som plager mange i helse- og utdanningssektoren, også her til lands.

Forfatteren tar høyde for denne kritikken. Han bygger tematikken rundt en detaljert omtale av det han ser som tre veier for velferden de senere årene: Markedsveien, New Public Managementveien og Tradisjonsveien. Han skriver at «verken Markedsveien eller NPM-veien har levert en klart bedre og billigere velferd slik som noen håpet». Heller ikke en ren forlengelse av Tradisjonsveien med forvaltningsstyring har han tro på. Dermed introduserer han sin fjerde vei, Samskapsmodellen, basert på det han omtaler som tillit og faglighet, med de ansatte som profesjonelle pådrivere.

Det er mye pent å si om denne visjonen, selv om den ikke er så entydig i sine praktiske konsekvenser. Men enkelte vil forbauses over at boken er så blottet for refleksjoner over velferdens drivkrefter. Er det en slags berøringsangst for velferdsstatens politiske historie og arbeiderbevegelsens kamp for sosial rettferdighet? Til tross for grundige analyser av virkningene av ulike slags velferdsreformer blir denne gjennomgangen preget av et nokså teknokratisk blikk på velferden. Boken fortjener likevel å bli lest av alle som vil delta i debatten om morgendagens velferd. Den er informativ og faglig sterk, men den får neppe mange hjerter til å banke.

\section{Steinar Westin}

Professor emeritus, Institutt for samfunnsmedisin Norges teknisk-naturvitenskapelige universitet 